\title{
乳幼児期における社会的参照の発達的意味および 兴の発達プロセスに関する理論的検討
}

\section{九州大学 遠藤利彦 ・ 東京大学 小沢哲史}

\section{Developmental meanings and processes of social referencing in infancy: A theoretical review}

Toshihiko Endo (Graduate School of Human-Environment Studies, Kyushu University, Hakozaki, Higashi-ku, Fukuoka 812-8581) and Tetsushi Ozawa (Graduate School of Arts and Sciences, University of Tokyo, Komaba, Meguro-ku, Tokyo $153-8902)$

When faced with the unknown or ambiguous, human beings tend to unconsciously consult others for guidance; they look to facial expressions or listen to vocal tones of others. Utilization of others as information sources, social referencing has been paid a lot of attention in developmental psychology, and its origin and development have been actively investigated and discussed. Nevertheless, there appear to be few integrated or comprehensive views on the developmental meanings and processes of social referencing in infancy. This paper reviews and evaluates various theoretical and empirical studies on early social referencing, and attempts to integrate them. Specifically, we first define social referencing and describe experimental paradigms to study infant social referencing. We next discuss its developmental function of effective learning facilitation and its requisites, such as understanding affect specificity and referential quality of information. We then consider some important problems in ontogeny of social referencing, in relation to theory of mind, attachment, and so on. And finally, we point out some unanswered questions and propose a new perspective for social referencing in daily situations.

Key words: social referencing, understanding of emotion, learning mechanism, theory of mind, infancy.

私たちは，常に，自身の内なる欲求や意志にしたが って，自律的に行動する存在ではない，人は，ひとた び他者との関係のなかに扔かれると，多かれ少なか れ，他者の影響を被る存在としてある。そればかり か, ときに, 他者が発する種々の情報を, 自ら能動的 に探索し，それを積極的に自身のふるまいに活かそう とする存在でもある。ことに，末知なるもの，不確か なるものとの遭遇は, 不可避的に, 人を社会的影響の もとにおくことになる、私たちはつい，その場に居合 わせた他者の顔をのぞき込み，またその声色の変化に 耳を立て，そのあいまいな事象や対象の意味を知万う とするのである。

このような行動傾向は, ある意味, 社会的存在とし ての人間の本質を坦間見させるものといえるわけだ が, 発達心理学の文脈においては, それが“社会的参 照” (social referencing) という術語で問題にされ，そ の起源と発達をめぐって熱い議論がなされてきたとい う経緯がある。特に, 近年, この社会的参照という現 象は，新たな理論枠のもと，子どもの種々の学習を支 える重要なメカ二ズムの一つとして, また，子どもの “心の理解”あるいは“心”そのものの成り立ちに密 接にかかわるものとして, 多くの発達研究者の注目を 集めるに至っている。本論は，こうした近年の社会的 参照研究の動向を打さえつつ, この現象の発達的意味 抢よびその発達プロセスの諸問題について広く理論的
考究を行うこととしたい. そのうえで, 批判的立場か ら, 現今の社会的参照研究に相対的に欠落している視 点をつまびらかにすることにしよう。

\section{1. 社会的参照とは何か}

\section{1 社会的参照の定義}

議論を展開していくに先立って,まずは社会的参照 という現象を学術的に定義づけておく必要があろう。 一般的に社会的参照については大別して 2 通りの定義 が流布しているといえる。一つは，“ある状況に対す る自身の解釈を構成する際に，他者の同一対象に対す る解釈を情報として活用すること”というものである (Campos, 1983; Feinman, 1982) (定義 A)。もう一つ は, “あいまいな状況に抢いて, 他者に情報を求め, その情報を用いて状況に対する自らの対処行動を調整 すること”というものである (e.g., Campos \& Stenberg, 1981; Klinnert, Campos, Sorce, Emde, \& Svedja, 1983; Feinman \& Lewis, 1983; Klinnert, 1984; Sorce, Emde, Campos \& Klinnert, 1985）（定義 B). 前 者はいわば, 社会的参照の意味を, 情報探索に限定し て考える立場であるのに対し, 後者は, それに加えて 行動調整という要素もその基本要件の一つとする立場 であるといえよう。研究者によっては，さらにこの二 つの間に情動調整という要素を組み入れて考える向き 
もある (Walden \& Knieps, 1996)。この見方によれ ば，“意味の不確かな対象と遭遇した際に生じた不安 定な情動状態を，他者が発する情報を活用し，その対 象の意味を知る(情報探索) ことによって建て直し (情動調整), さらにはその対象に対する自らの行動を 決定・実行する（行動調整）という一連のプロセス” こそが，社会的参照であるということになる（定義 C).

おそらく，“参照” (referencing) という語の一般的 な意味からすれば，現実の行動を調整することまで も，その概念規定の中に包捸することにはややいきす ぎの感がある，大人を想定して考えた場合，他者が発 する情報を積極的に求めたとしても，それをあえて選 択的に自身の解釈に活かさないということもありうる だろう。また, なんらかのかたちで解䊅にいかしたと しても, 別段, それによって自らの行動を変えない, あるいは，他者が発した情報にとわない行動をとるこ ともあろう。すなわち，情報を探索し活用すること と, 行動を調整することは必ずしも連動したものでは ないのである。しかし, 発達研究の文脈のなかでは, 通常, 定義 $\mathrm{A}$ よりも定義 B あるいは C がとられるこ とが多い。これは, 社会的参照研究に扔いて主たる夕 ーグットとなる乳幼児の場合，いまだ十分に言語を絡 めて他者に問い合わせることができず，まして自身の 内観を言語的に表明しえないために, 情報探索の有無 そのものが，外に現実に現れた行動上の変化をもって 判定されなくてはならないからである。いわば，実験 上の操作的な定義として定義 $\mathrm{B} や \mathrm{C}$ が多く採られて いるといえるわけだが，行動調整までもその成立要件 の一つとする定義上のしばりが, 日常的現象としてあ るさまざまな社会的参照に関して狭くかたよった見方 をもたらしたとの批判が一部にあることをここで付言 しておく (e.g., Walden, 1991).

\section{2 社会的参照研究の基本的枠組み}

既述のと扔り, 発達研究に打ける社会的参照は, 一 般的に行動調整までを含めて問題にされることが多い わけだが，ここでは，それが，具体的にどのような手 続きをもって取り出されるのかについて, より詳細に みておくことにしょう。まず，乳幼児にとって探索の 対象となる情報とは何かということであるが, それは 他者の顔や声あるいは行動に現れる種々の情動表出と いうことになる，言語をはじめとする象徵的な意味体 系の世界に入る以前の乳幼児にとって, 情動が，他者 との間をつなぐ最も重要なコミュニケーション・ツー ルである (e.g., Hobson, 1993; Lewis, 1993) ことを考 えれば，それは半ば当然のことといえるかもしれな い.

情動とは, 一般的に, ある事象に接した際の, 個体 のその事象に対する“評価”（appraisal）の反映とい
えるものである (e.g., Lazarus, 1991; Oatley, 1992). それだからこそ，私たちは，他者の情動表出から，そ の他者がある事象や対象に対して潜在的にどのような 心理的スタンスを有し，またどのような意味を帰属さ せているかをうかがい知ることが可能なのである。し かし，乳幼児段階からすでに子どもは成人と同様に， 情動の背後に広がるこうした意味の世界になんらかの 気づきをもちえているのだろうか。当然のことなが ら, 発達研究者の関心はその点に注がれることにな る。それを明らかにするために, 具体的な実験手続き として, 乳幼児を未知なるものや人に遭遇させ，その 際に乳幼児が身近にいる他者（主に養育者）に視線を 向けうるか否か, そしてその他者の情動表出の意味に そったふるまいをその未知なる対象に対してうまく組 織化しうるか否かを問うことになるのである。

これまでの研究では, 大別して (a) 視覚的断崖 (e. g., Sorce et al., 1985), (b) 見知ら奴人 (e.g., Boccia \& Campos, 1989; Feinman \& Lewis, 1983), (c) 動きや音 声をともなう新奇な玩具あるいは小動物（e.g., Gunnar \& Stone, 1984; Hornik \& Gunnar, 1988) とい う3 種類のものが, 乳幼児を不確実・不安定な心理状 態に扔くあいまいな刺激・状況として用いられてい る.

視覚的断崖とはもともと乳幼児の奥行き知覚の存在 を確かめるべく案出された実験装置 (Gibson\& Walk, 1960) であり, 深さ $30 \mathrm{~cm}$ から $1 \mathrm{~m}$ ほどの溝 のうえに厚い透明なガラス板が渡され, 乳幼児程度の 体重ならば十分にそのうえをハイハイして移動するこ とが可能となっている。実験のなかで, 乳幼児は, 魅 力的な玩具に近づくために，その深みのあるガラス板 の上をどうしても渡っていかなくてはならないという 状況に扔かれる。深み, そしてその上に置かれた透明 なガラス板などは, 乳幼児が日頃 (少なくとも自らの 運動をともなった経験としては）まだあまり経験して いないものであり, その意味で, 移動が可能なのかど うか, 不確実であいまいな対象といえるわけである.

見知らぬ人との遭遇は，いわゆる “人見知り” (stranger anxiety) に関する実験手続き（e.g., Horner, 1980）をそのまま用いたものとみることができ，そこ で乳幼児は, 突然部屋のなかに入ってきて, 自らに近 づいてくる, またときには, 自分に玩具を差し出した り，自分を抱き上げたりしようとする，見知ら成人 との対面を余儀なくされる。

新奇な玩具との遭遇は, 最も一般的に用いられてい る実験手続きであり, 子どもが座っている部屋のなか に, 見慣れない形をした玩具が，多くの場合，奇妙な 動きをしながら，また少し騒がしい音を立てながら入 ってくる. そこで, 子どもは, 好奇心をそそられる一 方で, なかば恐れや不安を抱き, 結果的に, あいまい で不安定な心理状態におかれることになる。 
こうした不確実状況に接するという条件設定で，子 どもの近くに身を扔く，母親をはじめとする，子ども にとっての親密な他者は, 意図的に, 快, 不快 (悲し み, 恐れ, 怒り，嫌悪など）の情動を，顔の表情ある いは声を通じて表出することを求められる。あるいは 表出を変化させずに一貫して中立的態度をとることを 求められる。

評価のポイントは，子どもが “参照視” (referential look）と呼ばれる明確な頭部回転をともなった注視行 動を身近な他者に対して向けうるかどうか，そしてそ こで感知した他者の情動表出に合致した態度や行動を 刺激に対してうまく構成しうるかどうかという点であ る。他者の情動がポジティヴな表出であるときに，当 該刺激に対して近接や接触といった行動をみせたり, あるいは自ら快の情動を表出するなどし，また，逆に 他者の情動がネガティヴな表出であるときに，刺激に 対して退却や回避の行動パターンを示したり，あるい は自ら不快や苦痛の情動を表出するなどした場合に， 一般的に，その子どもに扔いて社会的参照が明確に成 り立っていると判定されることになる。

こうした一連の実験手続きは，より自然で生態学的 妥当性の高い状沉において, 乳幼児の情動的コミュニ ケーションに対する理解の質と程度を把捉しようとい う試みのなかから生まれてきたものとされている (Campos \& Stenberg, 1981; Feinman, 1982). 社会的 参照の研究以前から乳幼児が各種情動表出の静止画や 動画に対して弁別的な反応を示すことはある程度知ら れていたわけだが，そこで問題になっていたのは，い わば物理的刺激としての情動表出の識別が可能である ということと, 各種表出の個別の意味を理解している ということを果たして等号で結びうるのかどうかとい うことであった. Campos \& Stenberg（1981）らは, 従来の社会的文脈を欠いた情動弁別実験からそのこと を知ることは不可能であると考え，現実に適応的行動 が必要となる状況のなかで, 各種情動表出に対する乳 幼児の “生きた”反応を体系的に吟味しょうと企図し たのである。その試みは，これまでにある程度の成功 を収めてきたと考えられる。現に，どの時点からどの ようなかたちの社会的参照行動が可能になるのか，そ の発達の里程標のようなものは，かなりのところ解 明・整理されてきているといえるからである。

しかしながら，親密な他者に注意を向け，その他者 の情動表出と合致する行動をとることが “ことごとく すべて”，適応上必要な情報を能動的に探索するとい う社会的参照そのもののメカニズムを意味することに なるのか，ときに，まったく別のモチべーションやメ カニズムに由来して同様の行動が生じる可能性は皆無 なのかといった，従来の実験パラダイムを根本から摇 さぶるような問いが，現在，新たに浮上してきてい る.こうした点については, 後に, 特に 3 節で改めて
考察を行うことにしたい。

\section{2. 社会的参照はいかなる発達的意味を有しているか}

ここでは, 社会的参照が発達的にみて, いかに着目 に值する現象であるかということについて，社会的参 照が子どもの発達全般にもたらしうるもの，そしてま た社会的参照を支え, 可能ならしめる発達的要素とい う二つの観点から，理論的な考究を試みることにした い.

\section{1 社会的参照 “が” 支えるもの}

発達早期に扔ける社会的参照が興味深いのは，一つ にはそれが，子どもが環境世界について種々の知識を 獲得し，また構造化していくうえできわめて効率的な 学習入カニズムとして機能すると考えられるからであ る。社会的参照は，その後の子どもの生活に深く関与 するであろうさまざまな状況や事象が，情動的重要性 という観点からして，どのように評価されるべきかと いうことに関する家族や社会の意味システムを徐久に 子どものなかに根づかせる貴重な学習ストラテジーと いえるのである (Saarni, 1999)。さらにいうならば, それは，人間の文化のなかにあらかじめ蓄えられたも のとしてある膨大な情報が，子ども自身の知識として 徐久に内在化されていく過程で，きわめて重要な役割 を担うものと考光られる。

Tomasello, Kruger, \& Ratner（1993）は人間特有の 文化的学習を支える基本的メカ二ズムとして，“模倣 学習” (imitative learning), “教示学習” (instructed learning), “協同学習” (collaborative learning) の 3 種類のものを仮定し, そのうち, 個体発生的に最も早 期に現れる模倣学習のなかに，この社会的参照を位置 づけている。彼らによれば，新生児段階からすでにみ られる身体的同調作用（動作模倣, 共鳴動作, 情動伝 染など）が，純粋に他者の外的行為や動作の忠実な再 現・模倣であるのに対し，それより遅れて生じる模倣 学習は, 行為の再現そのものよりも, ある対象に対し てその行為を起こそうとする他者の態度や心的状態の 理解に重きがあるのだという。換言するならば，行為 そのものの再現・習得ではなく, 行為の裏側にある意 味の習得であるところにその本質があるということな のだろう。

Tomaselloらは，社会的参照を含む模倣学習の進行 によって，子どもは他者“から”直接的に学ぶのみな らず，他者“を通して”間接的にも学ぶことが可能に なるのだと推察している。すなわち, 養育者をはじめ とする他者との直接的なやりとりのなかから，あるい は他者によって坅みに配慮され与えられる諸刺激か ら，何ものかを学ぶのみならず，他者の目標や視点， さらには種々の心的状態を感知することを通して, 自 らを取り巻く環境世界に関する知識を構築しうるとい 
うことである。こ机は，子どもが自ら当事者として， 試行錯誤的にある対象や事象との直接的経験を踏まな くとも，あるいはまた，自らリスクやコストを負うこ となく, 迅速で効率的な学習が可能であるということ を意味する。

Baldwin \& Moses（1996）はまた，社会的参照を， 情動表出のみならず言語などを含めて広く能動的に他 者に情報を求めていく“社会的情報収集”（social information gathering) のなかに位置づけ, 他の基本 的学習機構である “直接的探索” (direct investigation）抢よび “観察学習” (observational learning) と の根本的な違いについて考察を行っている。直接的探 索は系統発生的にみても, 個体発生的にみても最も原 初的な学習メカニズムとい光るものであり, 人間の子 どもも出生直後から外界の対象を種々の感覚器官を用 い, 能動的に探索することを通して, 対象の機能的な 意味と，それに対する自らの適応的ならるまいを学習 することができる (e.g., Piaget \& Inhelder, 1969).し かし, そこでの知識は, 自己と対象の直接的なかかわ りのみから発するものであり, ある意味, 外界に遍在 している他のいかなる情報も個体の知識獲得に活かさ れることはない。

また, 観察学習も直接的探索ほどではないにして も，広く他生物種にも認められるものであり（e.g., Mitchell, 1987), 人間の子どもも発達早期から, モデ ルとする他個体の行為とその帰結との “物理的” 関連 性を習得することができる(他個体の心的状態の理解 は必要ではない) (e.g., Meltzoff, 1988a, 1988b)。それ は, 生物個体における知識獲得の機会を大幅に増大さ せるものであるが，他者が情報の源あるいは運び手で あるという理解を前提とはしないために, 個体は, 自 身にはない情報を豊富に有するであろう他者に“意図 的に”焦点を合わせ，そこから“能動的に” 情報を引 き出すということをしない. 個体は，たまたま注意を 向けた顕在的な対象とそれに対する他個体の行為との 連なりから，いわば “受け身的に” 適切な行為パ夕一 ンを学習するのみである。

それに対して, 社会的参照あるいは社会的情報収集 の中核的特質は，その能動性にあるといえる。私たち が社会的生物としてあり, 自分自身よりも進んだ知識 を有する複数の個体と生活をともにするかぎり, ある 意味, 情報はいくらでもそこに転がっている。したが って, 能動的沉必要な情報を探索していけげ, 無限大 に近い知識を獲得することが可能なのである。このこ との重要性は，たと光ば, 必ずしもよい教え手とは限 らない, 配慮の乏しい養育者のもとで生育していかざ るをえない子どもを想定することで，よりあらわにな るといえるかもしれない. 養育者が自ら子どもに対し て積極的に情報を発しなくとも, 養育者が自然にふる まう日常生活者であるかぎり, 子どもはいくらでもそ
の養育者から豊かな情報を“盗む”ことができるので ある(よい教え手が不在でも，よい学び手は存在しう る)。人間の子どもが不遇で非応答的な環境下でも, ときに驚くほどの発達の弾力性 (resilience: e.g., Rutter, 1987）を発揮しうる背景に，こうした能動的 な社会的情報収集能力を仮定して考える研究者は少な くない (e.g., Shatz, 1987).

\section{2 社会的参照 “を” 支えるもの}

社会的参照が着目に值するもう一つの理由として, その成立に，人間の個体発生という点からしてきわめ て興味深い, いくつかの重要な発達的要素がからむと いう点を挙げることができる。多くの研究者の見解が 一致するところでは，情動の弁別的理解，そして情報 の指示的性質 (referential quality) の理解という, 少 なくとも 2 種の認知的コンピテンスの発達を礎石とし て, あるいはそれらと連動して, 社会的参照は初めて 成立するものらしい (e.g., Saarni, Mumme, \& Campos, 1998; Walker-Andrews \& Dickson, 1997).

Darwin（1872）に由来する基本情動理論（basic emotion theory) は, 各種情動の生物学的適応価を強 調し, 少なくとも喜び, 怒り, 恐れ, 悲しみ, 嫌悪, 驚きなどの情動については，それらを経験・表出する 機構はもちろん, それらを受容・理解する機構も，人 間の乳幼児に生得的に備わっていると仮定している (e.g., Ekman, 1992; Izard, 1991)。この仮説の当否に ついてはさまざまな議論がある（詳細は遠藤，1995， 1996）が，多くの研究者が，少なくとも生後 1 年目の 終わり頃までには，原初的な情動理解が成立するとみ なし，それが社会的参照実験に扔ける乳幼児のしかる ベきパフォーマンスに結びついていると考えているよ うである. 顔なり声なりに現机る各種情動表出の意味 を弁別的に理解しているからこそ, 拒むべきものには 忌避的な態度を示し，また近づくべきものには好意的 な態度をとることができるというのである。なお， Saarni（1999）は，社会的参照が，単に“他者”の情 動表出の意味を理解するのみならず，“自身”の主観 的情動状態をも的確に覚知する必要のある現象だと把 捉している。自身の不安定な情動状態を覚知している からこそ，それとは異なる他者の情動表出に焦点化す ることが可能だというのである。

情報の指示的性質の理解とは, いってみれば, 視線 なり表情なり発声なり, 他者のなんらかのふるまいあ るいはそこに含ま机る情報が，常にある特定の何もの か“についてのもの”であるということ[Brentano (1874/1973) や Searle（1983）などがいうところのい わゆる “aboutness”] を明確に認識しているというこ とである。Tomasello（1995a）にいうせれば，他者 を“何ものかを志向する主体” (intentional agent) と して理解しているということになろう。さらにいうな 
らば，自己と他者がある同一対象に対してともに注意 を向けていることの理解，あるいは自己-他者-対象と いう三項関係の表象が，社会的参照には必然的にから むことになると考えられる(Adamson, 1996; Klinnert et al., 1983; Messer, 1997). 子どもは，自身 が遭遇したあいまいな対象について他者に問合せをす るために，本来まずは，その他者の注意がどこにある かを確認する必要がある。そして，他者の注意が自身 と同じ対象に注がれていることを知ったうえで，他者 の発する情動的情報を，ほかの何ものでもない，まさ しくその対象の意味として活用することができるとい うわけである。

こうした情報の指示的性質の理解あるいは三項関係 の表象を，いわゆる“心の理論” (theory of mind：直 接的には知覚しえない自他の心的状態の基本的性質や 機能について人が潜在的に有している知識, 素朴理 論）（e.g., 子安・木下，1997；Premack \& Woodruff, 1978; Wellman, 1990）という観点から考えることも できる，近年，その“心の理論”の起源を発達過程の ぞの時点までさかの滦りうるかということに関する議 論がかまびすしいわけであるが，その一つの代表的立 場として, 生後 1 年目の後半になってほぼ同期して現 れるとされる共同注意 (joint attention：狭義の定義 としては，他者の頭部や視線の動きを察知し，その注 視方向に自身の注意を合わせる行為), 原叙述的コミ ュニケーション (protodeclarative communication: 指さしやしぐさなどをもって自身の注視点に他者の注 意を呼び込み，自身の心的状態を他者に伝達しようと する行為)，そして社会的参照などのいわゆる第二次 相互主観性 (secondary intersubjectivity: Trevarthen \& Hubley，1978）にかかわる発達現象の成立を重くみる 向きがある（e.g., Baron-Cohen, 1991a，1991b，1995; Bretherton, 1991; Reddy, Hay, Murray, \& Trevarthen, 1997).

確かに，子どもは，生後 1 年目の前半からすでに, 他者との間で一見“心”の介在を感じさせる，高度に 社会的なやりとりを展開することができる（遠藤， 1997)。他者の視線, 動き, 表情, 発声などに, 特異 な感受性をもって，かなりのところ随伴的な反応を示 しうるのである [Trevarthen (1979) がいうところの 第一次相互主観性 (primary intersubjectivity) に加 わる行為].しかし，これらの反応については，純粋 に身体的同調作用という観点から説明することができ ないわけではない（e.g., Lewis, 1991, 1995)。また，そ れは多くの場合，自発的なものではなく，養育者のあ る意味，過唾な解釈にそって巧みに導かれたものであ るといえる（遠藤, 1998; 荻野, 1997）. 養育者の微 笑に対して同じく微笑という行為をもって反応する子 どもは，必ずしも，養育者の快的な主観的情動状態を
“理解”したうえで，自らそれを共有しようと“意図” して，微笑しているのではないかもしれない。 そうし た内的プロセス，あるいは心というものに対する気づ きをいっさい介在させずに，外的に知覚できる行為 に，ほほ自動化されたかたちで連動・共鳴しているに すぎないかもしれないのである。

しかし，自己と他者の間に必ず，ある対象をはさむ 共同注意や原叙述的コミュニケーションや社会的参照 などに颃いては，一般的に，他者の心的状態に対する 覚知が必須要素になると考えられている(e.g., Gopnik \& Meltzoff, 1994). 人の注意や情動表出など は，直接，ある対象に対して物理的な影響をもたらす ものではない（視線を送っても微笑みかけても，対象 は不変のものとしてそこにあり続ける). したがって, 当然のことながら, 客観的に知覚される外的変化を通 じて，主体と対象との関係を知ることはできない。そ して，その潜在的な関係を知りえないかぎり，乳幼児 が，少なくともその関係の意味にそった適応的な行為 を起こしうるはずはないのである。

Moore（1996）によれば，多くの研究者が半ば常識 的な見解として，こうした“対象との距離を置いた行 為”の背後に, “心の理論”成立の中核的要件とされ る(a)主体と対象の間になんらかの “心理的”関係が 存在していること（たとえば，他者がある対象に対し て特別な興味を寄せている，何かを感じている，欲し ているなど) の理解，そしてまた(b)ある対象との間 にこうした心理的関係をもちうるという意味で自己と 他者が同等 (equivalent) であることの理解，が潜ん でいると仮定しているらしい（もっとも，後でもふれ るが Moore 自身はこうした見解に対して懐疑的であ る).もし，こうした見解を採るとすれば，社会的参 照は, 潜在的な “心の理論” (implicit theory of mind: Bretherton, 1991)，あるいは少なくとも“心の理論” の先駆体 (precursors of theory of mind: Tomasello, 1995a，1995b）に支えられて初めて成立するものだと もいえるわけである。

なお, Baldwin \& Moses (1996) は, 情動表出の弁 別的理解および情報の指示的性質の理解という要素に 加えて，概念的に規定されると打りの社会的参照が具 現されるためにはさらに二つの要素，すなわち，社会 的情報の潜在的有用性に関する理解と, 必要な情報を 引き出すためのスキルが必要になるとしている. 前者 は，いってみれば，実際に情報がもたらされる前か ら，自分自身の無知に関してある種の気づきをもち， 自身にはない有用な情報を潜在的に有しうる存在とし て他者を想定し，その他者から情報を得る必要性を明 確に認識しているということである、後者は, 単に他 者を視覚的, 聴覚的に知覚するばかりではなく，とき には指さしや身振り,さらには発達が進めば言語を交 
えながら, 必要な情報を他者から効率的に引き出すた めのスキルのことである。

これら二つの要素は, 社会的参照のいわば “能動 性”あるいは“自発性”にかかわるものと理解できる だろう、すなわち, 先述した定義にあるように, 社会 的参照を，情報を自ら探索し求める行動であるとすれ ば，それは，たまたま情動を発した他者の近くに居合 わせたから，結果的にその影響を被ることになったと いう“受け身的”あるいは“消極的”な反応とは，一 線を画すことになる。 ある対象海関する自己と他者の 知識の差異を理解し, 自身の無知を埋めるために,さ まざまなスキルを援用しながら, 他者が発する情報を “能動的” “積極的”に探索できるということこそが, 真の社会的参照に結びつくということなのだろう.

\section{3. 社会的参照の発達をめぐる諸問題}

提示刺激の違いによって若干の開きがあるが, 先に 示したような実験状況に扔いて, 仮説的に想定される とおりの社会的参照行動が現に認められるようになる のは, 一般的に生後 9 か月以降とみられている (e.g., Saarni, Mumme, \& Campos, 1998).これまでの研究 で, 最も早い段階に扮ける社会的参照の報告は, Boccia \& Campos（1989）によってなされたものであ り, それによれば, 生後 8 か月半の乳幼児が, 見知ら 㰠との遭遇に際し, 養育者に視線を向け, その情動 表出の意味にそったふるまいをみせたという.

Tomasello（1993）は，こうした社会的参照や共同注 意などの萌芽がほぼ同期して認められる生後 9 か月前 後を“9 か月の奇跡” と呼び, その時点に心的発達上 の大きなターニング・ポイントがあるのだろうと推察 している.

しかしながら, 生後 1 年目の後半という早期段階に 扔いてすでに, 社会的参照行動が, 先にみたような発 達的要素をすべて兼社備えた, いわば “完成体”とし てあり, その後, 不変のものとしてあり続けると把捉 することにはいささか無理があるように思われる。他 者の情動表出にそったしかるべき行動を対象に対して みせるという行動基準からすれば, 確かにさまざまな 月齢で同じょうに社会的参照行動が成立しているとい いうるにしても, 子どもがそれを行う状況, 活用する 情報の様式, 情報を引き出す方法, さらにはそれが生 じるメカニズムなどには, 確実に発達的変化が存在す ると考えられる (e.g., Baldwin \& Moses, 1996; Walden, 1991)。ここでは, 前述した, 社会的参照の 基礎と考えられる各種発達的要素とのからみを吟味し ながら, 社会的参照の発達的プロセスについて論考を 試みることにしたい.

\section{1 情動表出の弁別的理解にかかわる問題}

まず情動表出の弁別的理解という点からして, 早期
段階の社会的参照行動が真にこの要件を満たしたもの なのかどうかについて考えてみよう。これまでの社会 的参照実験の一つの問題点として, 比較的多くの研究 において, 情動的情報の様式が十分に統制されてこな かったという点が挙げられている (e.g., Saarni et al., 1998). 実験に参加した身近な他者, 特に養育者は, ほとんどの場合, 正負の情動を, 顔の表情, 発声, 身 振りなどを同時に“多重モード”で用いながら, 表出 してきたのである。そこで問題になるのは，子どもが 弁別的な理解を示しうるのは, 顔の表情に対してなの か, 情動の音声的特質に対してなのか, それとも行動 上の特質（特異な身振りや姿勢）に対してなのかとい うことである。

さらに，もう一点想定しておくべきことは，単一モ 一ドでたとえば顔の表情だけを変化させた研究（e.g., Sorce et al., 1985) に扔いて, 予測されたと扔りの結 果が得られたとしても, そもそも, それをもって真 に, 乳幼児が, 正負それぞれの表情の意味に対して弁 別的理解を示したといいうるのかどうかということで ある. 生後 1 年以内に扔いて養育者が子どもに対して 表出する情動はポジティヴなものが圧倒的に多く, 逆 に怒りや恐れといったネガティヴなものは相対的に稀 少であることが知られている (Kuchuk，Vibbert，\& Bornstein, 1986; Zumbahlen \& Crawley, 1996) (ハイ 八イや歩行など, 子どもの自発的運動が活発になり出 してから，それを制止しょうとして養育者のネガティ ヴな情動表出が急增する)。ということは, 特に負の 情動条件で, 子どもが行動制止や回避などの反応を示 しえたという場合，それがたとえば“警告”といった 情動の意味に関する適切な理解に基づいたものなの か, それとも, 養育者の顔面表出の見慣れなさ，扔よ び普段あまり経験しない養育者の応答性の低さなどに 起因したものなのか, 要因の分離が難しいということ になる (Mumme, 1993).

また，これに関連していって扔くならば，特に恐れ の表情を養育者に作らせた場合に，その表情がとかく 不自然なものになりがちであることが報告されている (e.g., Rosen, Adamson, \& Bakeman, 1992). 子どもは, 状況の不確かさに加えて, 養育者の様子や対応のあい まいさを経験しているかもしれず，それが子どもの刺 激対象に対する消極的な態度につながっている可能性 も否定できないのである (Baldwin \& Moses, 1996).

こうした疑問に完璧に答えうる知見はいまだ得られ ていないというべきである（Saarni et al., 1998）が, 少なくとも生後 1 年前後の早期段階に扔いて社会的参 照行動が確認されているのは，ほとんどの場合，顔と 声の情動的表出を同時に与えた実験においてである (e.g., Hirshberg \& Svedja, 1990; Hornik, Risenhoover, \& Gunner, 1987; Rosen et al., 1992). 顔面表出のみを 問題にした研究においては，概して社会的参照の存在 
をいぶかる否定的な結果が得られているようである (e.g., Zarbatany \& Lamb, 1985). Mumme, Fernald, \& Herrera（1996）は，生後 12 か月の子どもを対象に, 顔面表出のみを変化させる条件抢よび発声的特質のみ を変化させる条件の実験を行っているが, 結果は後者 の発声条件のみで, 子ぞもが情動の種類（快，恐れ） に応じて適切に反応しうるということを示すものであ った。また，社会的参照に限定したものではないが， Walker-Andrews（1997）は，乳幼児の情動知覚に関 するこれまでの研究を概観し，顔面表出に関する認識 が，発声に含まれる音感的調子に関する認識よりも遅 れて生じてくると結論している。

抢そらく, 生後 9 か月頃から認められるという発達 早期の社会的参照行動に拈いては，子どもは主に情動 の音声的特質 (あるいは複数モードからなる全体的特 質）を手がかりに状況の意味を判断しているのだとい えるかもしれない。元こから，生後 2 年目に入って 徐々に, 顔の表出のみからも必要な情報を抽出するこ とができるようになるのだうう。もっとも, 生後 2 年 目の後半にもなると, 当然, 子どもはある程度, こと ばの意味を理解するようになり, 少なくとも日常場面 では，養育者などの言語に含まれた情報をより活用す るようになることが想定される（Baldwin \& Moses， 1996).

な抢, こ机までの研究は総じて, 情動が正か負かと いうことに対する乳幼児の弁別的反応について知見を 積み重齐てきたといえるものの，恐れや怒りや嫌悪と いった特にネガティヴな情動間の差異についてはいま だほとんど有用な知見を得ていないことをここで付記 しておく。

\section{2 情報の指示的性質の理解にかかわる問題}

次に情報の指示的性質の理解ということについて吟 味してみることにしょう。もともと社会的参照の実験 が行われ始めた時点から，一部に，社会的参照 “らし き”行動は, 他者の情動がある特定対象との関連で生 じてきたという理解を前提としなくとも，別種のメカ ニズム, すなわち “情動伝染” (emotional contagion) あるいは “気分変容” (mood modification) を通じて 十分生起しうるのではないかという議論があった（e. g., Feinman \& Lewis, 1983). 子どもは別段, 他者の情 動が特定対象の意味を指し示していることを理解して いるから，それを用いて特異的にその対象に対する行 動を変えたのではなく，他者の情動に巻き込まれるか たちで自身の情動状態を大きく変えてしまい, その結 果, 行動全般に変化をきたしたのではないか, そして それが当該対象についても及んだということにすぎな いのではないかというのである（Boccia \& Campos, 1989).

この気分変容の効果に最初に着目した Feinman \&
Lewis（1983）は，養育者の恐れの表出に接した生後 10 か月览が, 提示刺激に対してのみ行動上の変化 (ネガティヴな態度) を示し, 養育者との関係につい てはポジティヴな相互作用を維持したことから, 気分 変容が行動全般に影響をもたらしたとは考えがたいと し, 乳幼児が指示-被指示の関係を理解していること を示唆している。しかし，愛着という観点から考えれ ば，見知ら好もの，恐いものとの遭遇時などに，身近 な他者とのポジティヴな関係を回復・維持しようとす るのはある意味, 自然なふるまいであり（Bowlby, 1969), Feinman らの観察は, 気分変容仮説を必ずし も完全に退けるものとはいえない（Baldwin \& Moses, 1996; Saarni et al., 1998).

その後, Hornik et al. (1987) は，より直接的証左 を得るべく，母親がある情動表出を向けた新奇な玩具 と, もともと実験室に置かれていた自由遊び用の玩具 に対して，生後 12 か月児が異なる反応を示すかどう かを問題にした（気分変容仮説が妥当であれば，他者 の情動の効果は両玩具に等しく及ぶことになる)。そ の結果, ポジティヴ条件よりもネガティヴ条件で当該 玩具に対する接触が有意に少なくなること，一方，自 由遊び用の玩具については条件にかかわらずその接触 に違いが認められないことなどが明らかとなった。確 かに, これは表面上, 気分変容仮説に対する十分な反 証となっているかにみえる，が，子どもは母親が当該 玩具を見ていたからではなく，自分自身にとってその 玩具が新奇でより顕著（salient）であったために，自 身の変容した情動状態をその玩具にたまたま結びつけ てしまったのかもしれない (Mumme \& Fernald, 1995).また, 自由遊び用の玩具は, ずっとその場に あり親近性が高く，かつ遊びやすい（少なくとも脅威 を与えない）ものであったために，(特にネガティヴ 条件において）慰撫や気晴らしの対象として機能した という可能性も否めない (Saarni et al,, 1998).

子どもが情動的情報の指示的性質を理解しているこ とを明確に示すためには，新奇性抢よび目立ちやすさ という点で同等の複数刺激を準備し，そのうえで，当 該刺激に対してのみ行動上の変化が生じ, かつそれが 他の刺激には及ばないことを明らかにする必要がある といえよう。現在までに，こうした要件を満たす研究 がすでに二つ行われている (Baldwin \& Moses, 1994; Mumme \& Fernald, 1995). そして, 方法に若干の違 いがあるが, 両研究とも，生後 12 か月時点ですでに， 情動表出の効果が当該刺激に対する反応において特に 顕著であることを明らかにしている。12 か児が， すでに情動的情報の指示的性質を理解しているらしい ということは, 生後 1 年前後の乳幼児が, 指さしをは じめとする種及の指示的身ぶりに敏感に反応する（e. g., Corkum \& Moore, 1995) という点からすれば，あ る意味，自然なことといえるのかもしれない。もっと 
も，気分変容による効果がまったく認められないわけ ではなく，たとえば，Baldwin \& Moses（1994）は， 当該刺激に比して明らかに少ないものの，大人から無 視された刺激のほうにも，若干，情動の質にそった行 動上の変化が現れうるということを見いだしている. また，複数の試行を重ねる実験において，先行試行で もたらされた情動状態の変化が, 次試行の行動に影響 を及泟す，いわゆる“持ち越し” (carry-over) 効果の 存在も認められており (Klinnert, 1984; Walden \& Baxter, 1989; Walden \& Ogan, 1988)，少なくとも早期 段階の乳幼児のふるまいに関しては, 厳密な意味での 指示-被指示の理解抢よびその結果としての情報探 索・行動調整というメカニズムのみならず, 情動伝染 や気分変容といった他の要因の介在も考慮しておく必 要があるのだろう。

\section{3 社会的参照と原初的な“心の理論”}

ここまでみてくると, 生後 9 か月頃に始まる社会的 参照は, ある程度, 情動の弁別的理解および情報の指 示的性質の理解を下敷きにしたものだといえるかもし れない。そして，その意味からすれば，先に見た原初 的な “心の理論”との関連も十分に想定できることに なる。乳幼児が漠然とではあっても，他者と対象との 心理的関係，すなわち他者がある対象をたとえばおも しろいものあるいは恐いものと“表象”していること を理解（表象）しているからこそ，換言するならば， ある種の “メ夕表象”をもち合わせているからこそ， そこに社会的参照が成立すると解釈できないことはな いのである (Baron-Cohen, 1991b).

しかし，こうした見方に対して疑念を表明する向き もある. Moore ら (Corkum \& Moore, 1995; Moore \& Corkum, 1994）は, Perner（1991）の表象発達理論な どに依拠しながら，こうした原初的な“心の理論”が 社会的参照や共同注意などを可能ならしめるというよ りも，むしろ，こうした行動の生起が先にあって，そ れが徐々に原初的な “心の理論”を生み出すという因 果の方向性を想定すべきであると主張している.

Perner（1991）によれば，発達早期の乳幼児の行動 は，基本的に現実に関する“単一の”表象あるいは心 的モデルに支配されており，またそうした表象は，新 情報に関する処理が行われるたびに次々と更新されて いく性質を有しているという。同時に二つ以上の表象 を有し，それらの間の比較などを通じて，複雑な情報 処理をなしうるようになるのは，早くとも生後 2 年目 の後半以降になるらしい.

Mooreらは，こうした発達早期に打ける表象処理 の制約を考えれば，たとえば，自己と他者の両方があ る対象に対して同時に注意を向けていること，あるい は意図や欲求といったある心理的スタンスを有してい ることを，一度に表象することはまず不可能であり
(いかなる意味でもメ夕表象など成り立っているはず もなく)，その意味で，生後 9 か月あたりから現実に 観察される社会的参照や共同注意などが，原初的な “心の理論”に支えられて生じているとは考えがたい と推察するのである。

Mooreらによれば，子どもは発達の早期段階から すでに, 道具的学習（オペラント条件づけ）および遊 びなどを通じた養育者などによるトレーニング (Bakeman \& Adamson, 1984)，あるいはある種の生得 的メカニズム (Baron-Cohen, 1995) によって, 他者 の視線の方向に，(他者の心的状態としてではなく, あくまでも子ども自身の直接的経験として）“何か㧍 もしろいもの”がありそうなこと，あるいは他者の情 動表出がなんらかの意味を提供するものであることを “結果的に”知ることになり，それがときに共同注意 や社会的参照を可能ならしめるのだという。たとえ ば，条件づけの考え方にしたがえば，他者の頭部回転 に合わせて，たまたま同じ方向を見たときにかなりの 確率で扔もしろいものあるいは快的なものなどが発見 されるという経験の蓄積を通して, 結果的に他者と同 じものに注意を向けること, すなわち共同注意が定着 していくというようなことである [現にCorkum \& Moore（1995）は，それまで自発的に共同注意を起こ したことのない乳幼児が，一連の条件づけを通じて， 共同注意を示しうるようになることを確かめている]. 社会的参照についていえば，やはり同じく道具的学習 により, 他者の情動表出のパターンと回避や接近とい った行動のしかるべき連合が習得され，結果的に，他 者の情動表出の知覚から, 乳幼児自身の適応的ふるま いが導かれるようになるというようなことである.

ただし，そこで重要なことは，いずれの場合に抢い ても, 乳幼児が, 他者の視線や表情が, その他者の特 定の対象に対するなんらかの心理的関係（意図や欲求 など）を示すものだという理解あるいは素朴理論をあ らかじめ有している必要がないということである。

Mooreらは, むしろ, そうした人と特定対象の心理 的関係についての理解, いってみれば原初的な “心の 理論”が，発達早期の共同注意や社会的参照によっ て，そしてまたそれに随伴して生起する乳幼児自身の 内的・心的経験を通じて, 徐々に生み出されてくるの だろうとしている. Mooreらの見解はあくまでも仮 説的なものであり，その当否をここで議論することは 控えるが，もし，こうした見解が妥当なものであるな らば，原初的な “心の理論” は, 社会的参照 “を” 支 えるものではなく，むしろ社会的参照“が”支えるも のだということになるのだろう。

ここで，原初的な “心の理論”との関連においても う一つ興味深いトピックを挙げておくことにしたい. それは，自閉症者に扔ける社会的参照の特異性にかか 
わるものである，自閉症者の“心の理論”をめぐって は実にかまびすしい議論がなされている (e.g., BaronCohen, 1995; Happé, 1994; Hobson, 1993）が, 自閉 症者が, 発達早期においてどのような社会的参照を示 すかについては，これまで必ずしも十分な知見が得ら れてこなかったといえる。その意味で, 部分的にこの 問題を扱った Bacon, Fein, Morris, Waterhouse, \& Allen（1998）の研究は特筆に值するものと考えられ る.

彼らは，意味のあいまいな音声を聞かされた際に， 知的水準の高低にかかわらず，自閉症児が総じて社会 的参照を行わないことを明らかにしている。高機能, 低機能いずれの自閉症児も健常児，精神遅滞児，言語 発達障害児に比して，周囲にいる大人を参照視するこ とが有意に少なかったのである. Bacon らはこの結果 を受けて, 社会的参照, すなわち他者からある対象に 関する意味を引き出すことの困難さが，自閉症という 障害の中核的特質の一つとなっており，それが “心の 理論”の特異性とも通底している可能性を論じてい る。もっとも, 彼らは, 社会的参照の少なさと特異な “心の理論”との関連性に関して, 前述した Moore 寄 りの立場を採り, 自閉症児においては, 情動調律 (affect attunement) や情動知覚の問題がより本質的な リスク要因としてあり，それらが，社会的参照の少な さを招来し，そしてひいては“心の理論”の発達に阻 害的な影響をもたらすのだろうと推察している。

\section{4 情報探索の能動性にかかわる問題}

社会的参照の前提条件として，上で議論した情動表 出の弁別的理解抢よび情報の指示的性質に関する理解 という二つの要素に加えて, Baldwin \& Moses （1996）が，社会的情報の潜在的有用性に関する理解 と, 必要な情報を引き出すためのスキルが必要になる と仮定していることは先に述べたと扔りである。ここ では発達過程とのからみでその点について多少とも考 察を試みることにしよう。

Baldwin らは, 生後 1 年前後の乳幼児が, 情動的情 報を与えられた際に，それをある対象との関係でうま く活用できることを否定しない。多くの研究者が社会 的参照の基本要素とみなす情動の弁別的理解と情報の 指示的性質の理解についていえば，確固たる事実とし て, 乳幼児が 1 歳前後からすでにその要件を満たす社 会的参照 “らしき” 行動を十分に示しうることを認め ている。しかし，彼らによ机ば，その時点の子どもは 情報のよき“消費者” (consumer) であっても“能動 的探索者” (active seeker) ではなく, 真の（概念的に 想定されるとおりの）社会的参照をいまだ実現できて いない可能性が高いという。確かに, 子どもは, ほと んどの実験場面において，かなりの確率で他者に自発
だいたいその確率が 69\%（Klinnert，1984）から 100 \%（Walden \& Ogan, 1988）の間にあるとみている]. が，彼らが問題にするのは，能動的注視が真に能動的 “情報探索”を意味するのかどうかということである。 すなわち，養育者などに視線を投げるとき，乳幼児 は, 情報源や情報の性質等を明確に理解し, その理解 にしたがって，自ら意図的に必要な情報を得ようとし ているのかということである。

まず, 彼らは, 本来, 子どもの日常一般の注視行動 の頻度をべースラインとして比較したときに, あいま いな対象に接した直後の注視行動が際立って多いのか どうかを問題にすべきだとする。なんら刺激がないと き，あるいは日頃見知った対象に接しているときとそ の注視活動に差がないとすれば，それは特別に情報探 索を意味するものではなく，乳幼児の一般的注視傾向 を反映するものにすぎないということになろう。しか し, 研究の現状としては, あいまいな対象と遭遇した 際の注視行動とその後におけるそれとの比較はある (e.g., Boccia \& Campos, 1989) ものの, 遭遇前と遭遇 直後の比較はいまだなされておらず，注視行動が純粋 情報探索欲求から生起したものかどうかは不明であ る. また, 発達早期（生後 6-13 か月）の子どもは, あいまいな刺激と接した際に養育者に視線を投げるに しても，そうするまでに平均して 1 分前後の時間を要 するという報告がなされている（Walden \& Ogan, 1988）（ちなみに，14一22 か月児の平均は 30 秒を超 える程度である)。 Baldwin らは, 乳幼児が養育者を 確実な情報源と認識し, 能動的に情報探索していると 考えるには，この反応潜時はあまりにも長く，乳幼児 の注視活動がもっと他の要因に起因している可能性は 否めないとしている.

Baldwin らは仮に譲歩して, 刺激対象と遭遇した直 後に, 乳幼児の養育者などに対する注視活動が際立つ て増大するということを受け入れるとしても，それを 能動的な情報探索の現れだと結論するにはなおも根拠 が希薄だという。彼らがそこで問題にするのは，知と 無知の識別ができ，(自身が無知である場合には）外 から情報を取り入机ることが有用で，かつ他者は自分 自身には欠けている情報を有している可能性があると いうことをあらかじめ理解していなければ，人は，情 報をいかにして誰から引き出すべきなのか，その見通 しを立てられないことはもちろん，そもそも，情報を 探索しようという欲求そのものをもたないであろうと いうことである。

しかし，知識というものに関する子どもの理解を問 題にした研究は, 生後 1 歳前後からすでに乳幼児が知 と無知の識別をなしうるということに対して総じて否 定的である。たとえば，子どもの自発的な日常発話の なかに，心的概念獲得の証左を見いだそうとした Bartsch \& Wellman（1995）は，子ぞもが “知ってい 
る”“知らない”といった人の知識状態にかかわる発 話をするようになるのは, 早くとも 3 歳以降になるこ とを明らかにしている。また，各種実験をもって，こ の問題にアプローチしている研究においても，3歳よ りも前に，こうした理解の萌芽を見いだしているもの は稀少である。かろうじて，O’Neill（1996）が2歳 半の段階にその予兆を認めているくらいである.

Baldwin らは，いずれにしても現段階までに，2歳 より前に知と無知の識別ができるということを示すデ ー夕はほとんど得られていないとして, 子どもが1歳 前後からすでに自発的な情報探索，ひいては厳密な意 味での社会的参照を行っているとは到底考えがたいと 結論している。

\section{5 愛着の観点からみる養育者に対する注視}

Baldwin \& Moses（1996）の論考が妥当なものであ るとすれば，生後 9 か月頃からすでに認められる，刺 激遭遇直後の養育者などに対する注視を私たちはどの ように解釈すればよいのであろうか. Baldwin らは， それを愛着行動の枠内で十分に説明が可能だとする.

Bowlby（1969，1973，1980）あるいはAinsworth, Blehar, Waters, \& Wall（1978）の愛着理論が仮定する ところでは, 生物はこの世に生を受けた時点から他個 体との近接を求めたり，近接関係を維持しようとする 傾向を本源的に備えているという。特にこうした傾向 は，人間の乳幼児のように，際立って移動能力にも摂 食能力にも乏しい生物個体にとっては, 安全と生存を 保障するうえで不可欠の働きをするということにな る. Bowlbyによれば，そうした近接欲求（愛着欲 求）は，後追いやしがみつきといった物理的近接行動 のみならず，ときに定位や発信といった遠隔的行動に よっても充足される。すなわち, 子どもは発達の最早 期段階から，養育者などに身体や頭部の向きを合わ せ，また視線を送り，場合によってはそこに微笑や泣 きなどの情動表出をからめることで, 最大限に養育者 などの関心を引き寄せ，それを通じて近接関係を維持 しょうとするのである (Sroufe, 1996)。

さて, あいまいな事象や対象との遭遇を余儀なくさ れる社会的参照実験において, 子どもは，かなりの確 率で, 恐れや不安などのネガティヴな情動経験をして いることが想定される. 愛着欲求および愛着行動が最 も活性化される場面が，ネガティヴな情動が喚起され る危機的な状況である（Bowlby，1969）ことをふまえ れば, 愛着行動のレパートリーの一つとしてある注視 行動が社会的参照実験に扔いて際立って生じやすくな るとしても, 別段, 不可思議なことではない。むし ろ，それはきわめて自然のことといえるだろう。すな わち，そこでの注視は，“情報を求める行動” (information-seeking behavior) ではなく，自身に対 する“慰搤を求める行動” (comfort-seeking behavior)
である可能性が否定できない゙ということである。ま た，子どもは特にネガティヴな情動状態になくとも， 養育者などとの間で，親和・提携（affiliation）の関 係を取り結漂うとする存在でもある(Bowlby, 1969)。たとえば，その一環として，子どもが，養育 者などとの間で， ある種の情動を共有しょうとして注 視行動 (affect-sharing behavior) を起こしたとして も,さほで驚くには当たらないだろう。

こうしたBaldwin らの見解にそうものとして, Dickstein, Thompson, Estes, Malkin, \& Lamb (1984) が得ている知見は実に興味深い。彼らは, 社会的参照 実験に扮ける子どもと養育者の距離を操作し, 距離が 大きくなればなるほど, あいまいな対象と遭遇した直 後の注視行動が増大するということを見いだしてい る。養育者との距離がもともと大きい状況とは, すで にして, ある程度, 愛着関係が啃かされている状況と いえる。そして，そこであいまいな対象に接すること は, 輪をかけて子どもを不安な状態におくことになる だろう。情報探索という観点からいえば，子どもの注 視行動に対する動機づけ（無知ゆえにあいまいで不安 定になっている心的状態を適切な情報を補うことで減 殺しようとする）はあくまでも子ども自身と対象との 関係から生まれるものであり, そこに本来, 養育者と の距離は影響を及ぼさないはずである。しかし，現に その影響が認められたということは，もともと子ども が情報探索以外の動機づけ，招そらくは愛着欲求によ つても注視行動を起こしているということをある程度 示唆するものといえるだろう.

また, Dickstein らは, 子どもの愛着タイプ（A 回 避型・B安定型・Cアンビバレント型：Ainsworth et al., 1978）と実験場面での養育者に対する注視活動と の関連性もみている。それによれば, 注視行動は, C アンビバレント型の子どもで最も多く, その後に B 安定型, $\mathrm{A}$ 回避型が続いたという。この順番は, 実 のところ, 養育者住対する接触・近接欲求の強さ (愛 着行動が活性化されやすい傾向）および養育者の位置 に対する注意樑さの順番と一致するものであり (Ainsworth et al., 1978), その意味で, この知見も, 愛着欲求を重要な動機づけ（の少なくとも一部）とし て, 注視行動が生じているのだということをある程 度，裏打ちするものといえよう。

Walden \& Baxter (1989) が得ている知見もまた, 基本的にBaldwin らの見解にそうものである. 彼ら は, 状況の親近性によって, 子どもの社会的参照に影 響が及ぶことを想定し，子どもにとって見慣れた保育 施設での子どもの養育者に対する参照視と, 初めての 実験室におけるそれとを比較・検討している。当初, 彼らは，見知ら如柷に打ける注視行動がより多くな ると仮定していたが，結果はそれとは逆のパターンを 示すものであった。すなわち, 親近性の高い保育施設 
における注視頻度のほうが有意に高かったのである。 これは一見逆説的な結果といえるわけだが，Walden らは，家を出るときから子どもがずっと養育者ととも にすごしていた実験室状況よりも, 通常, 養育者が子 どもを預けて立ち去り，また迎えに来るという保育施 設のほうが，まさに分離や再会が問題になるという点 で, 愛着システムの活性化を引き起こしやすく, 結果 的にそ机が養育者汶対する注視行動の増大を招来した のではないかと推察している。

なお，Baldwin らは，注視活動とともに，一見情報 を効率的に得上うと意図して用いているか涀える各 種のスキル, すなわち, 指さし, 対象の呈示, 発話・ 発問などについても，基本的に情報探索以外の観点か らの説明が可能であると主張する。それは，単に子ど も自身の注意の移行を示すものであったり，慰撫欲求 を示すものであったり, 具体的な援助要求（情報探索 ではなく養育者などから具体的な行為を引き出そうと する）あるいはまた情動共有欲求を示すものであった りする可能性が否めない。というよりはむしろ，少な くとも比較的早期段階に見られるそうした行動につい ては，情報探索以外の説明のほうがより説得力がある というのである。

議論がやや複雑になったので整理しておくならば, Baldwin らの主張は，あくまでも，子どもが最初か ら，自分にはない情報を“能動的に”探索しようとい う意図をもって注視行動を行わないということであ る. 子どもは，情動の弁別的理解や情動的情報の指示 的性質の理解を基盤として, 生後 9 か月くらいから 徐々に，タイミング良く情報が与えられた場合には， 養育者に対する注視を通じて “結果的に”事象や対象 の意味を知ることができるようになる，すなわち，先 述したように情報の“よき消費者”になりうる，しか し，それは情報探索の能動性を欠いているという意味 で，いまだ真の（定義ど扔りの）社会的参照ではな く，むしろ “社会的感受性” (social receptiveness) と でも呼ぶべきものである。 Baldwin らによれば，子ど もが “能動的探索者” (active seeker) になり, 真の社 会的参照が具現されるようになるのは，いくら早く見 積もっても生後 24 か月以降になるだろうという。こ うしたBaldwin らの見解は, いまだすべて傍証に支 えられた理論的なものでしかない。しかし，少なくと も，それが，“注視行動＝情報探索”という暗然の前 提にしばられた, 従来の社会的参照実験の枠組みを根 本から摇さぶるものであることは，ある程度確かなこ とであるように思われる。

\section{4. 現代社会的参照研究の相対的欠落点を問う}

スの諸問題について, 広く先行研究を概観・整理し, 可能なかぎり精細な議論を行ってきたつもりである. しかし, 筆者らは従来の研究の流れに, 相対的に欠落 している視点がいくつかあると考える. 最後に, そう した点について批判的論究を試みて扔くことにした い.

\section{1 社会的参照実験はどれだけ子どもの“コンピテ ンス”あるいは“能力”を測りえているか}

社会的参照の実験パラダイムは，個人が “一様に” ある対象や事象に対して“わからない”“あいまいで ある”という評価をし，その結果，不安定な情動状態 を経験すること，また，動機づけとしてそうした情動 状態の低減を欲するということを暗黙の前提としてい る。そして，そうした状況に扔ける一つの対処方略と して，能動的情報探索を行いうるか，上り具体的に は，他者の情動表出に積極的に注意を払い，自身の適 応的行動に役立てうるかを問題にするわけである。し かし，刺激の物理的等価性は心理的等価性を保証する ものではありえない（Lazarus, 1991)．当然のことな がら，同じ刺激に接したすべての個人がそれに対して 同じ評価をし，また同じ不安定な心理状態を経験し， そしてまた同じ動機づけを有しているとは限らないの である (Oatley, 1992)。このことは，実験における子 どものパフォーマンスが，情報探索を行いうるか否か というコンピテンスの差異というょりも，ある刺激状 況に対する評価や心的状態の差異を反映したものであ りうるという可能性を示唆する。

原理的に，社会的参照の実験パラダイムは，不安定 な情動状態を経験していながら情報探索を“行いえな い”(すなわち社会的参照のためのコンピテンスが末 発達な）子どもと，不安定な情動状態を経験していな いがゆえに情報探索を“行う必要のない”（すなわち 潜在的にコンピテンスを有していても社会的参照の動 機づけを有していない）子どもを分離できないのであ る。また，子どもは，場合によっては，不安定な情動 状態を有し, 潜在的に情報探索行動を起こしながら, 他者の情動的手がかりを不適切と判断し，あえてその 手がかりにそわない行動をとる可能性さえもある(こ うした場合，子どもは情報探索あるいは社会的参照を 行わない，あるいは行いえないと判断されてしまうこ とになりかねない)。

さらに，もう一つ厄介なのは，刺激との遭遇直後に 養育者に対する注視行動が生じたとしても，それが必 ずしも等質な評価および動機づけに起因して生じるわ けではないということである。それは，唯一，情報探 索欲求からのみ生じるのではなく, 実汇多様な状況評 価および欲求・動機づけに起因して生じうる可能性が あるのである. 先に Baldwin \& Moses（1996）の見解 についてみたが, 子どもの注視行動は, 近接欲求, 豲 
撫欲求，あるいはまた情動共有欲求などの現れかもし れない.このことは，たとえ，子どもが “結果的に” 他者の情動的情報の影響を受け，その情報の性質にそ つた行動を組み立てえたとしても，その行動の背後に あるメ゙カニズムは, 評価や動機づけという点からし て, 決して一様ではありえないということを意味す る。操作した情動の性質にそった行動を子どもがきっ ちりと示しえたか否かということを唯一の基準とする 従来の実験パラダイムでは，もともと明確な情報探索 欲求を有し“積極的に情報を取りに行った”子ども （ある意味，能動的な真の社会的参照行動を起こしえ た子ども）と，たとえば，恐れから近接欲求の高まり を覚え，養育者の存在を確かめに行った結果，その養 育者の“情動に受け身的に巻き込まれてしまった”子 ども（Baldwinらにいわせれば社会的感受性を有して はいても真の社会的参照行動を起こしえたとはいいが たい子ども）をほとんど分離できないのである.

もちろん，いくつかの改良を加えることによって， 評価や動機づけの差異といった要因の混入を最小限に 抑え, 真の社会的参照にかかわるコンピテンスや能力 をより敏感に取り出すことも可能かもしれない.たと えば，1種類だけではなく，多様な特質をもった刺激 を複数種, 準備し実験を行い, それらに対するパフォ ーマンスを精緻にかつ総合的に吟味すれば，わずかな がらでも従来よりは精確に子どものコンピテンスをう かがい知ることができょう。また，刺激との遭遇直後 の注視活動に関しても，単に注視が生じたか否かとい うことのみならず，それに随伴する種々のふるまいま でを含めて観察を行えば，それが情報探索を企図した ものなのか，それ以外の動機づけに基づくものなのか をある程度峻別できると考えられる。現に, Hornik \& Gunner (1988) や Desrochers, Richard, Decarie, \& Allard（1994）は，子どもがあいまいな心理状態にお かれ，明らかに他者が発する情動的情報を探索しよう としているならば, 子どもの発声や顔にしかるべき情 動表出がともない, また注視時間などの側面にも特異 な性質が現れるはずだとして, ややもすると一見同様 にみえてしまう諸行動間の識別を試みている。たとえ ば, Desrochersらは子どもが驚きか困惑かを示すこ と, あるいは子どもが刺激に対して 3 秒以上の注視を 行うこと, そしてその後に母親の表情を 1 秒以上注視 すること，という条件をクリアした場合に，それを参 照視であると操作的に定義づけている。

筆者らは，こうした実験手続きの改良を通して，子 どもの社会的参照にかかわるコンピテンスや能力をよ り㛜密に測定しようという方向性をいぶかるものでは ない。しかしながら，社会的参照実験が “原理的に” ある意味, 状況評価のプロセスと（情動制御方略とし ての）社会的参照との分離されえない“総合点”の差 異を取り出す（純粋に後者のコンピテンスのみを抽出
しうるものではありえない）ものである以上，やは り，こうした改良によって引き上げられる実験の精度 にも自ずと限界があるのではないかと考える。少なく とも, 私たちは, 社会的参照実験によって取り出され る子どものパフォーマンスのみをもって，その子ども のコンピテンスや能力の成否を判断するということに 対して，より慎重であるべきなのだろう。

\section{2 社会的参照実験の生態学的妥当性：“日常的現 象”としてある社会的参照の本質は何か}

本論のここまでの議論からもすでに明らかであろう が, 従来の研究のほとんどは, 社会的参照をもつぱ ら, 子ども個人の内なるコンピテンス・能力の反映と して扱ってきたものといえる. 発達心理学の一つの目 的が, ある発達現象洬する精細な夕イムテーブルを 作成すること，すなわち，一般的に何がどの時点でど のようなかたちで現れるかを時系列的に記述していく ことだとすれば，こうしたスタンスは半ば当然のもの と首肯できる。確かに, 等質な条件統制のもと, 社会 的参照の成否確率扔よび特質の変化をとらえ, 光れぞ れの年齢時における認知的コンピテンスの限界をつま びらかにすることを通じて, 平均的な発達の里程標を 構成してきたことの意味は当然相応に評価されてしか るべきものであろう。しかし，こうした研究の方向性 が, 真に “日常的現象”としてある, 社会的参照关の ものの実態に即したものであったかどうかについて は，もう少し慎重に考えてみる必要があるように思わ れる.

当然のことながら，社会的参照とは本質的に三項関 係の問題であり, 子どもと同一の対象に注意を注ぐ他 者の存在なくしてはいかなる意味でも成り立ちえない ものである。だからこそ, 現今の社会的参照の実験パ ラダイムは, もっぱら, 他者を子どもと同一対象に関 心を注ぎ，それに対して自らなんらかの評価をし，ま た情動的に反応する存在と仮定し, 現実にそうした他 者を配置することで種々の実験結果を得てきたのだと いえる。さらにいえば，そこでの他者は，基本的に子 どものふるまいとは独立・並行的にただ情動表出する 存在としてあり, 他方, 子どもは, 半ば “一方的に”, そうした他者の表出を有用な情報として“盗み”活用 する存在としてあるのである。しかし，日常の発達的 文脈に目を向けた場合，そもそもこうした状況はどれ だけ自然なものといえるのだろうか。日常的状況を考 えた場合，養育者をはじめとする他者は，もちろん実 験パラダイムで仮定されているようなふるまいをいつ さい，みせないこともあれば，逆に，仮定されている 以上の豊かなふるまいをみせることもある存在なので はないだろうか。

実験パラダイムで仮定された以上にふるまうという のは，養育者が，子どもと同時並行的にある対象を体 
験し自ら反応するだけではなく，その対象に注意を向 ける子どもの様子にも関心を払い, 子どもの状態に合 わせた行動をとろうとするということである。すなお ち, ある対象に対して自分自身, なんらかの評価をし 情動的に反応するだけではなく, 加えて, 子どもが自 身に向けてきた注視などの潜在的な意図を解釉し（た とえば，子どもは何かわからなくて困惑しているのだ ろうと推察して), それに応じて, 明らかな伝達意志 のもと, 自らの情動表出を操作するということである (たとえば，危なくないよということを伝えるために 微笑みを作る)。場合によっては, 養育者自身は, 当 初，子どもが注意を向ける対象に対してなんら情動的 に反応していないかもしれないし，あるいはまた，そ もそも子どもの関心がどこにあるかを特別に意識して いないかもしれない.むしろ, 子どもから注視や発声 といったシグナルを受けて “初めて”，子どもの関心 の所在を探し, あるいは推測し，それから子どもの心 的状態を考慮して, その時点で意図的になんらかの情 動表出を作るということも少なくはないのだろう.

従来の実験手続きが企図するものは，子どもが，自 分の周囲に転がっている適切な情報を, 能動的に探索 し，活用しうるか否か，そのコンピテンスの成否を探 ることであり，そのために，他者はいわば情報を“垂 梳す”存在としてそこに位置づけられていたといえ る。しかし, 日常場面に抢ける養育者などの他者は, むしろ多くの場合, 子どもが求める適切な情報を能動 的に“伝達”しょうとする存在だと考えられるのであ る. 日常的現象としてある社会的参照の多くは, 子ど もが他者の表出を情報として汲み活用するという一方 向的なものではなく, 子どもがシグナルを送出し, そ してそれを受けて養育者などが応答するという“双方 向的な社会的交渉”としてあると考えるのがより自然 であろう。

Walden ら (Walden, 1991; Walden \& Knieps, 1996) は，まさに，子どもの注視を養育者に対する子どもか らのシグナル (信号) であると考え, 社会的参照を, そのシグナルと, それに対する養育者の随伴的応答と の組合せという観点からとらえ直す試みをしている. 彼らの仮定する組合せとは以下 3 通りのものである. (a)子どもの養育者に対する注視（シグナル）が現実 に生じ, それに養育者が随伴的に応答する場合 (hit)。(b)子どもの養育者に対する注視が現実に生じ ているが，養育者がそれを見落とすか，それに随伴的 に応じない場合 (miss)。(c)子どもの注視が現実には ないにもかかわらず, 養育者が䛊ってなんらかのかか わりをしてしまう場合（false alarm）［信号検出理論 からすればこの他に注視（信号）がないことを正確に 認知し何も応答しないこと，すなわちコレクト・リジ エクション (correct rejection) の存在が想定されるわ
のはない].

彼らは，健常児と発達障害児抢よびその親を対象 に，日常の相互作用の特性を，こうした組合せの観点 から観察し，それと実験場面に扔ける子どもの社会的 参照行動の生起との関連性を検討している。その結果 はやや複雑であるが，発達障害児に関しては，随伴的 応答が少ないあるいはミスの多い養育者をもつ場合 に，その子どもの適切な社会的参照行動が生じにくい こと，あるいは，健常児でも (やや年長児の場合), フォールス・アラームの多い養育者をもつ場合に, 全 般的に抑止的行動パターンが強まり, 社会的参照行動 が生じにくくなることなどが明らかにされている。こ うした結果からみても, 子どもの社会的参照の現出・ 様相・展開が本質的に他者の配慮やふるまいのあり方 に依存せざるをえないものであることは半ば自明のこ とといえるのではないだろうか. 潜在的に子どもの側 に社会的参照の “準備状態”があっても, 他者がそれ を見落としたり，また自身に子どもが向けてきた注視 を問合せや参照という意味では解釈しないような場 合, そこに “具体的行為”としての社会的参照は少な くとも完全型としては実現しないのである.

少なくとも, 発達早期段階における現実の社会的参 照は，養育者と子どもとの双方向的な社会的交渉とし てあり，また多分に養育者側の巧みな配慮に支元られ てあるということに研究者はもっと積極的な関心を向 けてよいのではないだろうか。こうした視点の転換 は，子どもが養育者との間で経験する日々の関係性の あり方が, 社会的参照の成否扔よび発達にどのように かかわっているかという興味深い問いを惹起する。実 のところ, 従来の研究は, 社会的参照の “平均的な” 発達の里程標を構成することにはある程度成功してき たといえるが，その個人差抢よびその規定因に関する 分析は相対的に立ち後れているといわざるをえない (e.g., Saarni et al., 1998). Walden らが示している方 向性は今後, 社会的参照の発達メカニズムを明らかに するうえで，より重要性を增してくるに違いない.

\section{5. 結 び}

今回は特に社会的参照に焦点をしぼって議論を構築 したわけだが，それが自己-他者-対象という三項関係 の問題であるかぎり, 本来ならば, 共同注意や原叙述 的コミュニケーションなどの現象とあわせて, より広 く, 早期社会的コミュニケーションの発達として論を 構成することも可能であったろう。しかし, 本論では 紙数の都合でそれを断念せざるをえなかった。今後の 課題として，こうした類似現象間の理論的架橋を図る 作業が残されたということを確認して，ひとまずは, ここで論を結ぶことにしたい。 


\section{文献}

Adamson, L. B. 1996 Communication development during infancy. Boulder, CO: Westview Press.

Ainsworth, M. D. S., Blehar, M. C., Waters, E., \& Wall, S. 1978 Patterns of attachment: A psychological study of the strange situation. Hillsdale, $\mathrm{NJ}$ : Erlbaum.

Bacon, A. L., Fein, D., Morris, R., Waterhouse, L., \& Allen, D. 1998 The responses of autistic children to the distress of others. Journal of Autism and Developmental Disorders, 28, 129-141.

Bakeman, R., \& Adamson, L. B. 1984 Coordinating attention to people and objects in mother-infant and peer-infant communication. Child Development, 55, $1278-1289$.

Baldwin, D. A., \& Moses, L. J. 1994 Early understanding of referential intent and attentional focus: Evidence from language and emotion. In C. Lewis \& P. Mitchell (Eds.), Children's early understanding of mind. Hillsdale, NJ: Erlbaum. Pp. 133-156.

Baldwin, D. A., \& Moses, L. J. 1996 The ontogeny of social information gathering. Child Development, 67, 1915-1939.

Baron-Cohen, S. 1991a The development of a theory of mind in autism: A case of specific developmental delay. Psychiatric Clinics of North America, 14, 3350.

Baron-Cohen, S. $199 \mathrm{lb}$ Precursors to a theory of mind: Understanding attention in others. In A. Whiten (Ed.), Natural theories of mind: Evolution, development, and simulation of misreading. Oxford, UK: Blackwell. Pp. 233-252.

Baron-Cohen, S. 1995 Mindblindness: An essay on autism and theory of mind. Cambridge, MA: MIT Press.

Barrett, K., \& Campos, J. 1987 Perspectives on emotional development: II. A functionalist approach to emotions. In J. Osofsky (Ed.), Handbook of infant development. 2nd ed. New York: Wiley. Pp. 555-578.

Bartsch, K., \& Wellman, H. M. 1995 Children talk about the mind. New York: Oxford University Press.

Bertenthal, B., Campos, J., \& Barett, K. 1984 Selfproduced locomotion: An organizer of emotional, cognitive, and social development in infancy. In $\mathrm{R}$. Emde \& R. Harmon (Eds.), Continuities and discontinuities in development. New York: Plenum. Pp. 175-210.

Boccia, M., \& Campos, J. J. 1989 Maternal emotional signals, social referencing, and infants' reactions to strangers. In N. Eisenberg (Ed.), New directions for child development. Vol. 44. San Francisco: Jossey-Bass. Pp. 25-49.

Bowlby, J. 1969 Attachment and loss. Vol. 1. Attachment. New York: Basic Books.
Bowlby, J. 1973 Attachment and loss. Vol. 2. Separation. New York: Basic Books.

Bowlby, J. 1980 Attachment and loss. Vol. 3. Loss. New York: Basic Books.

Brentano, F. 1973 Psychology from an empirical standpoint. (Trs. by A. C. Rancurello, D. B. Terrell \& L. L. McAlister) London: Routledge \& Kegan Paul. (Original work published 1874.)

Bretherton, I. 1991 Intentional communication and the development of an understanding of mind. In D. Frye \& C. Moore (Eds.), Children's theories of mind: Mental states and social understanding. Hillsdale, NJ: Erlbaum. Pp. 49-75.

Bretherton, I., \& Beeghly, M. 1982 Talking about internal states: The acquisition of an explicit theory of mind. Developmental Psychology, 18, 906-921.

Campos, J. J. 1983 The importance of affective communication in social referencing: A commentary on Feinman. Merrill-Palmer Quarterly, 29, 83-87.

Campos, J., Hiatt, S., Ramsay, D., Henderson, C., \& Svejda, M. 1978 The emergence of fear on the visual cliff. In M. Lewis \& L. Rosenblum (Eds.), The origins of affect. New York: Wiley.

Campos, J. J., \& Stenberg, C.R. 1981 Perception, appraisal and emotion: The onset of social referencing. In M. E. Lamb \& L. R. Sherrod (Eds.), Infant social cognition: Empirical and theoretical considerations. Hillsdale, NJ: Erlbaum. Pp. 273-314.

Corkum, V., \& Moore, C. 1995 Development of joint visual attention in infants. In C. Moore \& $\mathrm{P}$. Dunham (Eds.), Joint attention: Its origins and role in development. Hillsdale, NJ: Erlbaum. Pp. 6183.

Darwin, C. 1872 The expression of the emotions in man and animals. Appleton. (Reprinted by University of Chicago Press, 1965).

Desrochers, S., Richard, M., Decarie, T. G., \& Allard, L. 1994 Developmental synchrony between social referencing and Piagetian sensorimoter causality. Infant Behavior and Development, 17, 303-309.

Dickstein, S., Thompson, R. A., Estes, D., Malkin, C., \& Lamb, M. E. 1984 Social referencing and the security of attachment. Infant Behavior and Development, 7, 507-516.

Ekman, P. 1992 An argument for basic emotions. Cognition \& Emotion, 6, 169-200.

遠藤利彦 1995 乳幼児期における情動の発達とはた らき麻生武・内田伸子 (編) 講座生涯発達心 理学 2 人生への旅立ち一一胎児 $\cdot$ 乳児・幼児前期 一一金子書房 Pp. 129-162.

(Endo, T. 1995 The development and function of emotions in infancy. In T. Asao \& N. Uchida (Eds.), The psychology of life-span development $\mathrm{Vol}$. 2. The beginning of human life: From embryonic period to early childhood. Tokyo: Kaneko Books. Pp. 129162.) 
遠藤利彦 1996 喜怒哀楽の起源——情動の進化論・ 文化論一岩波書店

(Endo, T. 1996 The origin of emotions: Evolutionary and cultural considerations on emotions. Tokyo: Iwanami Books.)

遠藤利彦 1997 乳幼児期に扔ける自己と他者, そし て心一一関係性,自他の理解, および心の理論の関連 性を探る—— 心理学評論, 40,57-77.

(Endo, T. 1997 Relationships and infants' early understandings of self, other, and mind: Theoretical examination into the relations among relationships, self/other understanding, and theory of mind. Japanese Psychological Review, 40, 57-77.)

遠藤利彦 1998 乳幼览期における親子の心のつなが り—心の発達を支えるものとしての関係性— 丸野俊一・子安増生（編）子どもが “こころ”に 気づくとき ミネルヴァ書房 Pp. 1-31.

(Endo, T. 1998 The mind-interface between infants and their parents: The relationships as facilitator of mental development. In S. Maruno \& M. Koyasu (Eds.), When children became aware of mind. Kyoto: Minerva Books. Pp. 1-31.)

Feinman, S. 1982 Social referencing in infancy. Merrill Palmer Quarterly, 28, 445-470.

Feinman, S., \& Lewis, M. 1983 Social referencing at ten months: A second-order effect on infants' responses to strangers. Child Development, 54, 878887.

Gibson, E. J., \& Walk, P. D. 1960 The visual cliff. Scientific American, 202, 64-71.

Gopnik, A., \& Meltzoff, A. N. 1994 Mind, bodies and persons: Young children's understanding of the self and others as reflected in imitation and "theory of mind" research. In S. T. Perker, R. W. Mitchell, \& M. L. Boccia (Eds.), Self-awareness in animals and humans. New York: Cambridge University Press. Pp. 166-186.

Gunner, M. R., \& Stone, C. 1984 The effects of positive maternal affect on infant responses to pleasant, ambiguous, and fear-provoking toys. Child Developments, 55, 1231-1236.

Happé, F. 1994 Autism: An introduction to psychological theory. London: UCL Press.

Hirshberg, L. M., \& Svejda, M. 1990 When infants look to their parents: I. Infants' social referencing of mothers compared to fathers. Child Development, $\mathbf{6 1}$, 1175-1186.

Hobson, R. P. 1993 Autism and the development of mind. Hove, UK: Lawrence Erlbaum Associates.

Horner, T. M. 1980 Two methods of studying stranger reactivity in infants: A review. Journal of Child Psychology and Psychiatry, 21, 203-219.

Hornik, R., \& Gunner, M. R. 1988 A descriptive analysis of infant social referencing. Child Development, 59, 626-634.

Hornik, R., Risenhoover, N., \& Gunner, M. R. 1987
The effects of maternal positive, neutral, and negative affective communications on infant responses to new toys. Child Development, 58, 937-944.

Izard, C. 1991 The psychology of emotions. New York: Plenum.

Klinnert, M. D. 1984 The regulation of infant behavior by maternal facial expression. Infant Behavior and Development, 7, 447-465.

Klinnert, M. D., Campos, J. J., Sorce, J. F., Emde, R. N., \& Svejda, M. 1983 Emotions as behavior regulators: Social referencing in infancy. In R. Plutchik \& H. Kellerman (Eds.), Emotion: Theory, research and experience. New York: Academic Press. Pp. 5786.

子安増生・木下孝司 1997 〈心の理論〉研究の展望 心理学研究, 68, 51-67.

(Koyasu, M., \& Kinoshita, T. 1997 Review of the research on "theory of mind." Japanese Journal of Psychology, 68, 51-67.)

Kuchuk, A., Vibbert, M., \& Bornstein, M. H. 1986 The perception of smiling and its experimental correlates in three-month-old infants. Child Development, 87, 1054-1061.

Lazarus, R. 1991 Emotion and adaptation. New York: Oxford University Press.

Lewis, M. 1991 Ways of knowing: Objective selfawareness or consciousness. Developmental Review, 11. $231-243$.

Lewis, M. 1993 The emergence of human emotions. In M. Lewis \& J. M. Havilland (Eds.), Handbook of emotions. New York: Guilford Press. Pp. 223-235.

Lewis, M. 1995 Aspects of self: From systems to ideas. In P. Rochat (Ed.), The self in infancy: Theory and research. Amsterdam: Elsevier. Pp. 95115.

Meltzoff, A. N. 1988a Infant imitation and memory: Nine-month-olds in immediate deferred tests. Child Development, 56, 62-72.

Meltzoff, A. N. 1988b Infant imitation after a 1week delay: Long-term memory for novel acts and multiple stimuli. Developmental Psychology, 24, 470476.

Messer, D. 1997 Referential communication: The making sense of the social and physical worlds. In G. Bremner, A. Slater \& G. Butterworth (Eds.), Infant development: Recent advances. Hove, UK: Psychology Press. Pp. 291-309.

Mitchell, R.W. 1987 A comparative-developmental approach to understanding imitation. In P.P. G. Bateson \& P. H. Klopfer (Eds.), Perspectives in ethology. Vol. 7. New York: Plenum. Pp. 183-215.

Moore, C. 1996 Theories of mind in infancy. British Journal of Developmental Psychology, 14, 19-40.

Moore, C., \& Corkum, V. 1994 Social understanding at the end of the first year of life. Developmental Review, 14, 349-372. 
Mumme, D. L. 1993 Rethinking social referencing: The influence of facial and vocal affect on infant behavior. Unpublished doctoral dissertation, Stanford University, Stanford, CA.

Mumme, D. L., \& Fernald, A. 1995 Infants' use of gaze in interpreting emotional signals. Unpublished manuscript.

Mumme, D. L., Fernald, A., \& Herrera, C. 1996 Infants' response to facial and vocal emotional signals in a social referencing paradigm. Child Development, 67, 3219-3237.

Oatley, K. 1992 Best laid schemes: The psychology of emotions. Cambridge: Cambridge University Press.

荻野美佐子 1997 コミュニケーションの発達 井上 健治・久保ゆかり（編）子どもの社会的発達 東 京大学出版会 Pp. 185-204.

(Ogino, M. 1997 The development of communications. In K. Inoue \& Y. Kubo (Eds.), Social development in childhood. Tokyo: University of Tokyo Press. Pp. 185-204.)

O'Neill, D. K. 1996 Two-year-old children's sensitivity to a parent's knowledge state when making requests. Child Development, 67, 659-677.

Perner, J. 1991 Understanding the representational mind. Cambridge, MA: Bradford Books/MrT Press.

Piaget, J., \& Inhelder, B. 1969 The psychology of the child. London: Routledge.

Premack, D., \& Woodruff, G. 1978 Does the chimpanzee have a "theory of mind"? Brain and Behavioral Sciences, 1, 515-526.

Reddy, V., Hay, D., Murray, L., \& Trevarthen, C. 1997 Communication in infancy: Mutual regulation of affect and attention. In G. Bremner, A. Slater \& G. Butterworth (Eds.), Infant development: Recent advances. Hove, UK: Psychology Press. Pp. 247-274.

Rosen, W. D., Adamson, L. B., \& Bakeman, R. 1992 An experimental investigation of infant social referencing: Mothers' messages and gender differences. Developmental Psychology, 28, 1172-1178.

Rutter, M. 1987 Psychosocial resilience and protective mechanisms. American Journal of Orthopsychiatry, 57, 316-331.

Saarni, C. 1999 The development of emotional competence. New York: Guilford.

Saarni, C., Mumme, D. L., \& Campos, J. J. 1998 Emotional development: Action, communication, and understanding. In W. Damon \& N. Eisenberg (Eds.), Handbook of child psychology. 5th ed. Vol. 3. New York: Wiley. Pp. 237-309.

Searle, J. R. 1983 Intentionality: An essay in the Philosophy of mind. New York: Cambridge University Press.

Shatz, M. 1987 Bootstrapping operations in child language. In K. E. Nelson \& A. van Kleek (Eds.),
Children's language. Vol. 6. Hillsdale, NJ: Erlbaum. Sorce, J. F., Emde, R. N., Campos, J., \& Klinnert, M. D. 1985 Maternal emotional signaling: Its effect on the visual cliff behavior of 1-year-olds. Developmental Psychology, 21, 195-200.

Sroufe, L. A. 1996 Emotional development: The organization of emotional life in the early years. New York: Cambridge University Press.

Tomasello, M. 1993 The interpersonal origins of self concept. In U. Neisser (Ed.), The perceived self: Ecological and interpersonal sources of selfknowledge. Cambridge: Cambridge University Press. Pp. 185-204.

Tomasello, M. 1995a Understanding the self as social agent. In P. Rochat (Ed.), The self in infancy: Theory and research. Amsterdam: Elsevier. Pp. 449-460.

Tomasello, M. 1995b Joint attention as social cognition. In C. Moore \& P. Dunham (Eds.), Joint attention: Its origins and role in development. Hillsdale, NJ: Erlbaum. Pp. 103-130.

Tomasello, M., Kruger, A. C., \& Ratner, H. H. 1993 Cultural learning. Behavioral and Brain Sciences, 16, 495-552.

Trevarthen, C. 1979 Communication and coorperation in early infancy: A description of primary intersubjectivity. In M. Bullowa (Ed.), Before speech. New York: Cambridge University Press. Pp. 321347.

Trevarthen, C., \& Hubley, P. 1978 Secondary intersubjectivity: Confidence, confiding, and acts of meaning in the first year. In A. Lock (Ed.), Action, gesture, and symbol: The emergence of language. New York: Academic Press. Pp. 183-229.

Walden, T. A. 1991 Infant social referencing. In J. Gerber \& K. Dodge (Eds.), The development of emotion regulation and dysregulation. Cambridge, England: Cambridge University Press. Pp. 69-88.

Walden, T. A., \& Baxter, A. 1989 The effect of context and age on social referencing. Child Development, 60, 1511-1518.

Walden, T., \& Knieps, L. 1996 Reading and responding to social signals. In M. Lewis \& M.W. Sullivan (Eds.), Emotional development in atypical children. Mahwah, NJ: Lawrence Erlbaum. Pp. 2942.

Walden, T. A., \& Ogan, T. A. 1988 The Development of social referencing. Child Development, $\mathbf{5 9}$, $1230-1240$

Walker-Andrews, A. S. 1997 Infants' perception of expressive behaviors: Differentiation of multimodal information. Psychological Bulletin, 121, 437-456.

Walker-Andrews, A. S., \& Dickson, L. R. 1997 Infants' understanding of affect. In S. Hala (Ed.), The development of social cognition. Hove, UK: Psychology Press. Pp. 161-186. 
Wellman, H. M. 1990 The child's theory of mind. Cambridge: MIT Press.

Zarbatany, L., \& Lamb, M. E. 1985 Social referencing as a function of information source: Mothers versus strangers. Infant Behavior and Development, 8, 25-33.

Zumbahlen, M., \& Crawley, A. 1996 Infants' early referential behavior in prohibition contexts: The emergence of social referencing? Paper presented at the meetings of the International Conference on Infant Studies, Providence, RI.

-1999. 12.20 受稿, 20000.7.1 受理一 